\title{
Cellular and molecular aspects of fat metabolism in the small intestine
}

\author{
BY PHILIPPE BESNARD, ISABELLE NIOT, ANDRE BERNARD \\ AND HELENE CARLIER \\ Laboratoire de Physiologie de la Nutrition, Ecole Nationale Supérieure de Biologie Appliquée à la \\ Nutrition et à l'Alimentation (ENSBANA), Université de Bourgogne, 1, Esplanade Erasme, \\ F-21000 Dijon, France
}

\section{Aspects cellulaire et moléculaire du métabolisme lipidique au niveau de l'intestin grèle}

\section{RÉSUMÉ}

Le rôle énergétique, structural et fonctionnel des acides gras à longue chaîne (AGLC) dans l'organisme dépend de leur biodisponibilité intestinale. Les données actuelles tendent à montrer que deux mécanismes distincts et complémentaires permettent aux AGLC de traverser la membrane apicale de l'entérocyte: une diffusion simple et un transport faisant intervenir au moins deux protéines membranaires, la plasma-membrane fatty acid-binding protein (FABPpm) et la fatty acid transporter (FAT). On ignore actuellement quelle est l'importance relative de ces deux mécanismes et s'il existe une spécialisation de ces protéines vis à vis des différents AGLC. Ces derniers sont ensuite pris en charge au niveau intracellulaire par les fatty acid-binding proteins cytosoliques $(F A B P c)$. L'entérocyte a la particularité d'exprimer deux FABPc differentes, la I-FABPc et la L-FABPc, dont les rôles respectifs restent à élucider. Elles apparaissent cependant déterminantes pour la constitution d'un pool intracellulaire d'acides gras non estérifiés et la protection contre les effets cytotoxiques des acides gras libres. La L-FABPc pourrait être également impliquée dans la modulation de l'activité de certaines enzymes du métabolisme lipidique et dans le contrôle de la differenciation et de la prolifération cellulaire. Après activation par la long-chain acyl-CoA synthétase (ACS), les AGLC sont soit pris en charge par l'acyl-CoA-binding protein (ACBP), soit directement métabolisés (estérification, transformation et oxydation). L'ACBP semble exercer une double fonction à la fois en constituant un pool d'acides gras activés et en assurant leur transport intracellulaire. Les donnés actuelles suggèrent donc que les fonctions des FABPc et ACBP sont coordonnées et complémentaires. Durant la période postprandiale, les AGLC sont majoritairement réestérifiés en triacylglycérols (TAG) à la surface du réticulum endoplasmique lisse par l'intermédiaire de la voie des 2monoacylglycérols. La microsomal TAG transfer protein (MTP) assure le passage des TAG néo-synthétisés à l'intérieur du réticulum endoplasmique où associés avec les phospholipides, le cholestérol estérifié ou non et les apoprotéines ils constituent les pré-lipoprotéines. La structuration définitive en lipoprotéines (chylomicrons, VLDL et HDL) a lieu au niveau de l'appareil de Golgi avant exportation vers la lymphe. Au niveau de l'entérocyte, la régulation de l'expression des protéines clefs du métabolisme lipidique est complexe et multiple. Par exemple, il est établi que l'induction des apoprotéines intestinales par des régimes hyperlipidiques est d'origine post-transcriptionelle. En revanche, des travaux récents portant sur l'effet d'hypolipémiants 
proliférateurs de péroxysomes de la famille des fibrates montrent que certaines lipid-binding proteins (FAT, FABPc, ACBP) sont contrôlées par un mécanisme coordonné d'origine transcriptionnel impliquant une famille de transprotéines nucléaires: les peroxisome proliferator-activated receptors. Ces transrégulateurs sont également activés par certains AGLC. Or il est établi que ces AGLC contrôlent plusieurs gènes impliqués dans le métabolisme lipidique de l'adipocyte via cette famille de transrégulateurs. Les travaux actuels s'orientent donc vers la mise en évidence d'un mécanisme régulateur semblable au niveau l'entérocyte.

It is well established that lipids play essential roles in the cell either as an energy source, membrane components or precursors of lipid mediators which exert a large variety of regulatory effects. More recently, fatty acids (FA) have been shown also to directly modulate both ion-channel activation and synaptic transmission (Ordway et al. 1991) and to exert cellular regulatory functions as signal-transducing molecules (Ailhaud et al. 1994; Sumida, 1995).

Lipids represent about $40 \%$ of the daily energy intake in the Western diet. Triacylglycerols (TAG), which are mainly composed of long-chain FA (LCFA, $\geqslant \mathrm{C}_{16}$ ), are the major form of dietary lipids and are referred to as fats. The other lipids found in the diet are cholesteryl esters (CE) and phospholipids (PL). TAG are hydrolysed in the proximal part of the small intestine to form 2-monoacylglycerols (MAG) and FA through the action of the pancreatic juice. FA absorption from intestinal lumen involves several steps: diffusion through the unstirred water layer (UWL), passage through the plasma membrane, cytosolic activation and esterification, lipoprotein formation and exocytosis. Although the present report describes each of these steps, it focuses more particularly on new insights into the area of intestinal LCFA absorption and metabolism in the small intestine: LCFA uptake by enterocytes, lipid-binding proteins (LBP) and LCFA as putative transcriptional regulators of proteins involved in fat metabolism. For this reason, it is additional to recent reviews published in this field of research (Davidson, 1994; Tso, 1994).

FA are hydrophobic molecules which are transported and metabolized in the aqueous environment of the organism. The structure of FA (number of $\mathrm{C}$ atoms and degree of unsaturation) determines their relative water solubility which plays a crucial role in their behaviour and metabolic use. During the postprandial period the LCFA, which are more hydrophobic than the short- and medium-chain FA, are after several metabolic steps preferentially directed towards the lymph, while the shorter-chain FA are essentially found in the blood, bound to albumin. Three strategies are used to solubilize LCFA: formation of mixed micelles, binding with cellular proteins and formation of lipoprotein complexes. Under standard diet conditions, these events occur in the proximal part of the gut (upper third of the jejunal villi). Indeed, this complex organ is organized along the cephalo-caudal and crypt-to-villus axes in regions characterized by a variable phenotypic expression producing regional specialization of function.

\section{CELLULAR UPTAKE OF LONG-CHAIN FATTY ACIDS}

The first step of absorption is the entry of LCFA from the bulk lumen phase into the aqueous barrier lining the enterocytes. The water overlying the microvilli of enterocytes is not in equilibrium with the bulk aqueous phase observed in the lumen of the small 
intestine. It constitutes a diffusion barrier which is referred to as the UWL. The UWL, which has a thickness of several hundred micrometres, requires the presence of mucus and constitutes a low-pH compartment (Shiau et al. 1985). Since the solubility of free LCFA in an aqueous medium is very limited, they will gain access to the microvilli of enterocytes as mixed micelles in association with bile salts. The micellar solubilization increases the aqueous concentration of LCFA 100-1000-fold (Tso, 1994). At the surface of the brush border, the presence of an acidic microclimate promotes micellar diffusion and dissociation. Indeed, at low $\mathrm{pH}$ the protonation of LCFA reduces their solubility in the micelles and, thus, promotes their release (Shiau, 1981).

How LCFA move across the biological membranes is a subject of controversy. Since they have a lipophilic character, passive diffusion through the phospholipid bilayer was thought to be the exclusive mechanism involved in FA uptake. For instance, all FA from octanoate $\left(\mathrm{C}(8: 0)\right.$ to arachidonate $\left(\mathrm{C}(20: 4 n 6)\right.$ exhibit rapid transbilayer movement $\left(t_{1 / 2}\right.$ $<1 \mathrm{~s}$ ) in the un-ionized form across small egg phosphatidylcholine vesicles (Kamp et al. 1993). Considering the fast movement of FA across this protein-free phospholipid bilayer, these authors suggest that a need for a transport protein to increase FA movement across a membrane is unlikely. However, this concept is challenged by the isolation and the characterization of several plasma-membrane proteins (plasmamembrane fatty acid-binding protein (FABPpm; Stremmel et al. 1985a), P22 (Trigatti et al. 1991), fatty acid translocase (FAT; Abumrad et al. 1993), fatty acid transfer protein (FATP; Schaffer \& Lodish, 1994)) which exhibit high binding affinity for LCFA. Among the numerous lipid-binding proteins expressed in the enterocyte (Table 1), two membrane proteins are found: FABPpm and FAT.

\section{Plasma-membrane fatty acid-binding protein}

FABPpm is a $40 \mathrm{kDa}$ protein found in various organs including liver (Stremmel et al. 1985a), small intestine (Stremmel et al. 1985b), heart and adipose tissue (Potter et al. 1987) and placenta (Campbell et al. 1994). This membrane carrier protein is related to mitochondrial glutamic-oxaloacetic transaminase (Berk et al. 1990) and the mitochondrial isoform of aspartate aminotransferase (Stump et al. 1993). FABPpm seems to have large transport competence since it exhibits high binding affinity not only for LCFA but also lysophosphatidylcholine, MAG and cholesterol (Stremmel, 1988). Immunocytochemical studies demonstrate that FABPpm is expressed in the apical tips of the brush-border villus and crypt of the jejunum and ileum; in contrast, none is found in oesophageal and colonic mucosa (Stremmel et al. 1985b). It is speculated that FA transport across the jejunal microvilli might be driven by an active $\mathrm{Na}$-dependent process similar to the hepatocellular uptake of LCFA (Stremmel, 1987, 1988). However, the fact that pre-incubation with monospecific FABPpm antibody induces only a partial inhibition of the absorption of LCFA by jejunal explants strongly suggests the existence of a dual uptake mechanism consisting of a passive diffusional transport process and active carrier-mediated translocation (Stremmel, 1988). The regulation of FABPpm expression is poorly understood since the cloning of the protein has not yet been performed.

\section{Fatty acid transporter}

Recently, an $88 \mathrm{kDa}$ membrane protein, homologous to CD36 glycoprotein (Tandon et al. 1989), was identified then characterized in rat adipocytes by labelling with 
sulpho-N-succinimidyl derivatives of LCFA under conditions where FA uptake was significantly inhibited (Harmon et al. 1991; Abumrad et al. 1993). This protein, termed FA transporter (FAT), seems to be involved in facilitating membrane permeation of LCFA and is highly expressed in various tissues including small intestine (Abumrad et al. 1993). In the rat, FAT mRNA level is slightly higher in jejunum, the main site of fat absorption, than in duodenum and is low in ileum. No transcript is found in stomach and colon. A gradient of FAT expression also exists along the crypt-to-villus axis since the FAT is constitutively expressed in the jejunal epithelial cells located in the upper half of the villus, while it is undetectable in the crypt and submucosal cells. These results are confirmed by immunofluorescence using a monospecific antibody raised in the rabbit against the rat FAT protein. In the jejunal mucosa, the fluorescence is limited to the brush border of enterocytes. No signal is found in the goblet cells. This localization and the fact that FAT mRNA level is strongly enhanced along the small intestine by chronic high-fat diets are consistent with the postulated role for this protein in membrane transport of FA (P. Besnard, H. Poirier and P. Degrace, unpublished results).

In conclusion, although the LCFA move rapidly across the artificial protein-free lipid bilayer, FA carrier proteins may be required within membranes to promote cellular uptake of LCFA from the complex environment. Indeed, in the particular case of the enterocyte, the lipid bilayer is not freely accessible to FA because of the high glycoprotein level (mucopolysaccharides from mucus and cell coat) found near the microvilli. The membrane FA-binding proteins expressed in the small intestine might sequester the FA, facilitating their membrane translocation by the formation of a FA gradient. The conformation of FAT, with most of the protein in an extracellular hairpin and with a number of stretches of hydrophobic amino acids forming small hydrophobic pockets (Abumrad et al. 1993), suggest that this protein might act as the LCFA cellular uptake promoter in the small intestine.

\section{INITIAL INTRACELLULAR EVENTS}

Once translocated across the microvillus membrane of the enterocyte, LCFA are reversibly and non-covalently bound to cytosolic fatty acid-binding proteins $\left(\mathrm{FABP}_{\mathrm{c}}\right)$ before being activated by long-chain acyl-CoA synthetase (EC 6.2.1.3; ACS). The acyl-CoA esters formed will be either metabolized in endoplasmic reticulum, mitochondria and peroxisomes or bound to acyl-CoA-binding protein (ACBP) to constitute an intracellular acyl-CoA pool (Fig. 1).

\section{Cytosolic fatty acid-binding proteins}

For several years, the $\mathrm{FABP}_{\mathrm{c}}$ have been the focus of extensive studies and several reviews have been performed recently (Glatz et al. 1993; Veerkamp et al. 1993; Veerkamp, 1995; Veerkamp \& Maatman, 1995). The FABP $_{c}$ are $14-15 \mathrm{kDa}$ cytosolic proteins unrelated to $\mathrm{FABP}_{\mathrm{pm}}$ (Table 1), which exhibit high affinity for saturated and unsaturated LCFA. They belong to a multigenic family of LBP including presently

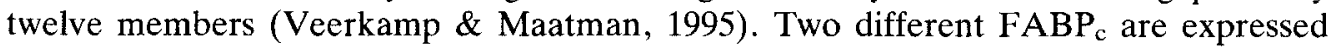

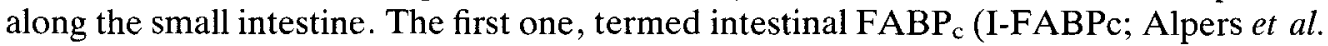
$1984)$ is strictly confined to this organ, while the second one, termed liver FABP $_{c}$

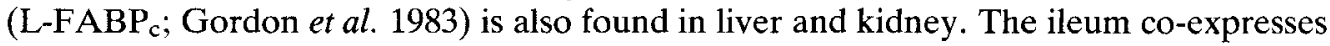




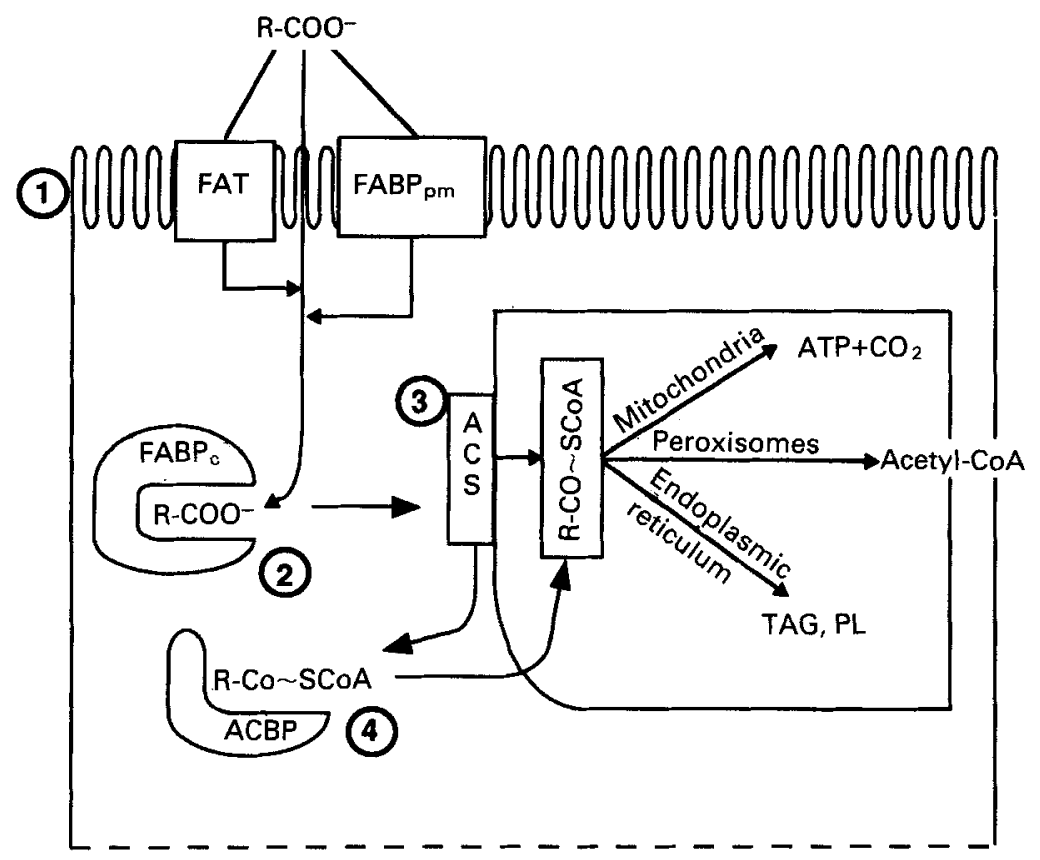

Fig. 1. Putative role of the cytosolic and plasma-membrane fatty acid-binding proteins $\left(F A B P_{c}\right.$ and $F A B P_{p m}$ respectively) and acyl-CoA-binding protein (ACBP) in the small intestine. 1, Membrane transport of long-chain fatty acids (LCFA); 2, cytosolic LCFA pool; 3, activation of LCFA; 4, cytosolic acyl-CoA pool. FAT, fatty acid transporter; ACS, long-chain acyl-CoA synthetase (EC 6.2.1.3); TAG, triacylglycerols; PL, phospholipids.

another member of the $\mathrm{FABP}_{\mathrm{c}}$ family which binds both bile salts and FA: the ileal LBP

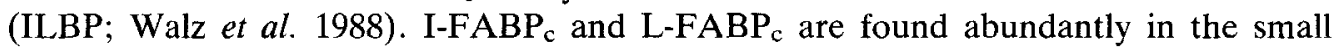
intestine (2-3\% of total proteins) and their respective mRNA encode $1-2 \%$ of the total intestinal mRNA (Bass et al. 1985). The intestine maintains a gradient in the expression of fatty acid-binding protein (FABP) genes along the cephalo-caudal and crypt-to-villus axes, the higher expression being found in the tip of the jejunal villi (Shields et al. 1986). The organization of the intestinal and liver $\mathrm{FABP}_{\mathrm{c}}$ genes is similar since they contain four exons and three introns (Sweetser et al. 1987). The introns vary markedly in size. However, they interrupt the coding sequences at the same position. There is an extensive evolutionary conservation of the primary structure of these genes with up to $80 \%$ of homology between human and rat L-FABP . In contrast, I-FABP $_{c}$ and L-FABP ${ }_{c}$ are poorly related within a species (only $28 \%$ of sequence homology in the rat; Chan et al. 1985; Sweetser et al. 1987). The three-dimensional structure of the Escherichia coliderived rat $\mathrm{I}-\mathrm{FABP} \mathrm{P}_{\mathrm{c}}$ was established by $\mathrm{X}$-ray crystallography. The protein consists of ten anti-parallel $\beta$ strands organized into two orthogonal $\beta$ sheets forming a clam shell conformation. The first two $\beta$ strands are connected by two $\alpha$ helices by which the protonated FA may enter the clam structure. The carboxylate group of the FA is coordinated to the protein through a network of ionic-hydrogen bonding interactions involving several polar amino acid side chains and water molecules within the cavity (Sacchettini et al. 1988; Sacchettini \& Gordon, 1993). The tertiary structure of the 


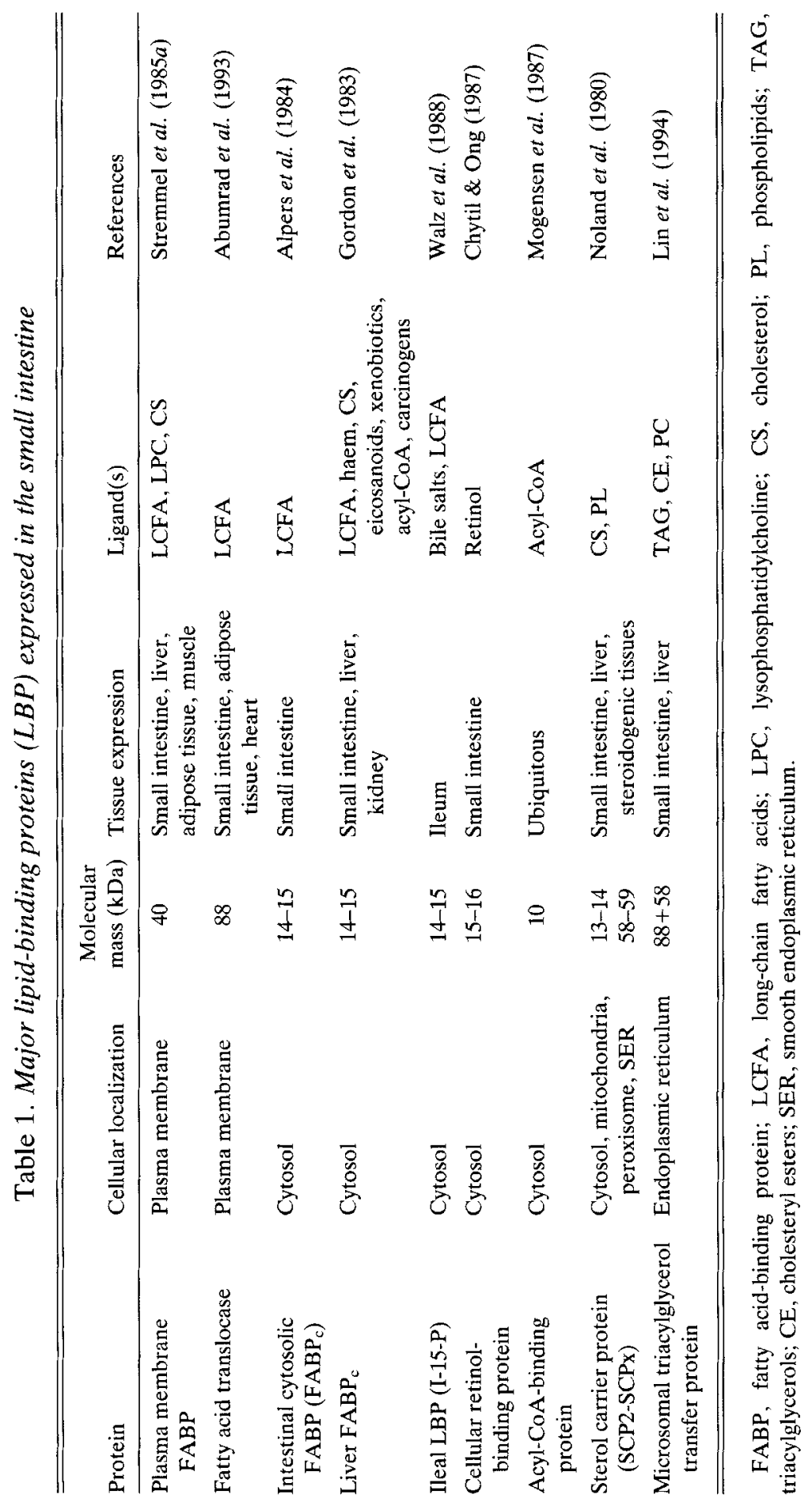


Table 2. Binding parameters of cytosolic fatty acid-binding protein $\left(F A B P_{c}\right)$ expressed in the small intestine

(Mean values and standard deviations)

\begin{tabular}{|c|c|c|c|c|c|c|c|}
\hline \multirow{4}{*}{$\begin{array}{l}\text { No. of binding sites . . } \\
\text { Affinity of binding sites . . }\end{array}$} & \multirow{3}{*}{\multicolumn{2}{|c|}{$\begin{array}{c}\begin{array}{c}\text { Intestinal } \\
\text { FABP }_{\mathrm{c}}\end{array} \\
1 \\
\text { High }\end{array}$}} & \multicolumn{4}{|c|}{ Liver $\mathrm{FABP}_{\mathrm{c}}$} & \multirow{4}{*}{$\begin{array}{c}\text { References } \\
\text { Cistola et al. } \\
(1989,1990)\end{array}$} \\
\hline & & & \multirow{2}{*}{\multicolumn{2}{|c|}{ High }} & \multirow{2}{*}{\multicolumn{2}{|c|}{ Low }} & \\
\hline & & & & & & & \\
\hline & Mean & $\mathrm{SD}$ & Mean & SD & Mean & SD & \\
\hline \multicolumn{8}{|l|}{ Dissociation constant (nM) } \\
\hline Palmitate $16: 0$ & 30 & 2 & 23 & 2 & & & \multirow{6}{*}{ Richieri et al. (1994) } \\
\hline Stearate $18: 0$ & 6 & 1 & 9 & 1 & & & \\
\hline Oleate $18: 1 n-9$ & 39 & 9 & 9 & 2 & 62 & 25 & \\
\hline Linoleate $18: 2 n-6$ & 140 & 40 & 23 & 3 & 420 & 250 & \\
\hline Linolenate $18: 3 n-3$ & 480 & 260 & 69 & 12 & 1000 & 500 & \\
\hline Arachidonate $20: 4 n-6$ & 350 & 140 & 48 & 9 & 420 & 130 & \\
\hline
\end{tabular}

L-FABP $\mathrm{C}_{\mathrm{c}}$ has not yet been reported, although crystals have been obtained from various mammalian species. The characteristics of ligand binding to I-FABP $c$ and L-FABP ${ }_{c}$ have been extensively studied. It is well established that (1) L-FABP has a binding capacity of $2 \mathrm{~mol} \mathrm{FA} / \mathrm{mol}$ protein in contrast to $\mathrm{I}_{-\mathrm{FABP}}$ which has a stoichiometry of 1 mol FA per mol protein (Lowe et al. 1987; Cistola et al. 1989) and (2) $\mathrm{L}-F A B P_{c}$ can bind a large variety of hydrophobic ligands while I-FABP ${ }_{\mathrm{c}}$ only binds FA (Veerkamp et al. 1991). Most dissociation constants $\left(K_{d}\right)$ reported in the literature are about $1 \mathrm{~mm}$ with little difference in the affinities of FA for I-FABP $\mathrm{F}_{c}$ and $\mathrm{L}-\mathrm{FABP} \mathrm{P}_{\mathrm{c}}$ and in the binding of various FA to the same FABP $_{c}$ (for review, see Veerkamp et al. 1991). However, recently Richieri et al. (1994), using a fluorescent probe technique, have reported quite different findings. They compared the affinities for various $\mathrm{FA}$ of six different $\mathrm{FABP}_{\mathrm{c}}$, including the intestinal and liver forms. The $K_{d}$ are low, ranging from about 2 to $1000 \mathrm{~nm}$. I-FABP and $\mathrm{L}-\mathrm{FABP}_{\mathrm{c}}$ exhibit similar $K_{d}$ values for saturated LCFA. In contrast, one of the binding sites of the L-FABP ${ }_{c}$ exhibits a higher affinity for unsaturated LCFA than the single binding site of the I-FABP . The two binding sites of the L-FABP ${ }_{c}$ are equivalent for saturated FA but differ in affinity by about 10 -fold for unsaturated FA, confirming the existence of high- and low-affinity binding sites (Table 2).

The suggested functions generally assigned to $\mathrm{FABP}_{\mathrm{c}}$ include: the facilitation of cellular FA uptake and trafficking, FA targeting towards different metabolic pathways, protection against the cytotoxic effects of free FA, modulation of enzyme activity involved in lipid metabolism. Recently, roles in signal transduction pathways (Glatz et al. 1995 ) and in cell proliferation (Sorof, 1994) have also been reported. Although the significance of the two $\mathrm{FABP}_{\mathrm{c}}$ types in the intestinal mucosa is always unclear, several explanations have been proposed. In contrast to other cell types using FA, the enterocyte takes up FA from two sources, the intestinal lumen and the blood. In an attractive hypothesis, Alpers et al. (1984) suggest that the $\mathrm{I}_{-\mathrm{FABP}} \mathrm{P}_{\mathrm{c}}$ might be involved in the transfer of lumen FA for TAG synthesis while L-FABP ${ }_{c}$ is involved in the transfer of blood-borne FA for oxidation and phospholipid synthesis. Another hypothesis is based on the difference in the binding specificity of the two $\mathrm{FABP}_{\mathrm{c}}$. It is suggested that 
I-FABP ${ }_{c}$ would transport only FA of lumen and blood origin, while L-FABP essentially transport other hydrophobic ligands playing the role of intracellular albumin (Cistola et al. 1989).

\section{Fatty acid activation}

To our knowledge, in contrast to the liver, fatty acid activation is little known in the small intestine. Activation of LCFA is the first reaction in cellular FA metabolism. In the liver, this reaction is catalysed by ACS (Tanaka et al. 1979). Mitochondria, endoplasmic reticulum and peroxisomes contain ATP-dependent ACS activity (Krisans et al. 1980) which is membrane-bound. In the endoplasmic reticulum and peroxisomes the active site of the ACS is cytosolic. The mitochondrial ACS is an integral enzyme of the outer membrane. In liver ACS has the same amino acid composition in the three organelles, suggesting the existence of a single enzyme (Suzuki et al. 1990). It is established that ACS synthesis is down-regulated by acyl-CoA and, thus, enhanced by ACBP and L-FABP . $_{\text {. }}$ In liver, ACS mRNA and ACS activity are increased by a high-fat diet and treatment with fat-lowering drugs of the fibrate type (Schoonjans et al. 1993).

\section{Acyl-CoA-binding protein}

The acyl-CoA-binding protein (ACBP) is an ubiquitous $10 \mathrm{kDa}$ cytosolic protein which binds fatty acyl-CoA with high affinity. Unrelated to the $\mathrm{FABP}_{\mathrm{c}}$ family, the ACBP is identical to diazepam-binding inhibitor protein, a mammalian brain neurotransmitter (Knudsen et al. 1989). Unlike FABPc, a single form of ACBP is found in organisms. It is particularly highly expressed in the liver, kidney and small intestine (Knudsen, 1990). ACBP has a stoichiometry of $1 \mathrm{~mol}$ acyl-CoA per mol protein. In vitro binding capacities for different acyl-CoA have been determined using a bovine recombinant ACBP (Rasmussen et al. 1994). The binding affinity depends on the length of the acyl chain $\left(K_{d}\right.$, 0.24 (SD 0.02) $10^{-6} \mathrm{M}$ and 0.45 (SD 0.02) $10^{-13} \mathrm{M}$ for octanoyl-CoA and hexadecanoylCoA respectively; Rasmussen et al. 1994), with the higher affinity for long-chain acyl esters, but it is independent of the number of double bonds (Rosendal et al. 1993). ACBP has a high degree of binding specificity since it binds neither free CoA nor FA with measurable affinities. The promoter region of the rat ACBP gene reveals several characteristic features of housekeeping genes (Mandrup et al. 1993), which suggests that the protein exerts a basic biochemical function. The ACBP gene consists of four exons and three introns. The eighty-six amino acid residues are organized in four $\alpha$ helices which are folded into a boomerang structure (Knudsen et al. 1993; Kragelund et al. 1993). ACBP seems to exert a dual function of acyl-CoA pool former and intracellular acyl-CoA transporter. Indeed, the over-expression of ACBP in yeast increases dramatically the pool of long-chain acyl-CoA esters (Mandrup et al. 1992) and in vitro, the ACBP is able to transport acyl-CoA esters to mitochondria or microsomes and donate them to $\beta$ oxidation or TAG synthesis (Rasmussen et al. 1994).

In conclusion, $\mathrm{FABP}_{\mathrm{c}}$ and $\mathrm{ACBP}$ might play complementary and coordinate functions in the cell: first, bringing the LCFA to membrane ACS and second playing a role of shuttle between the organelles removing the acyl-CoA from a membrane to offer them to another membrane. 


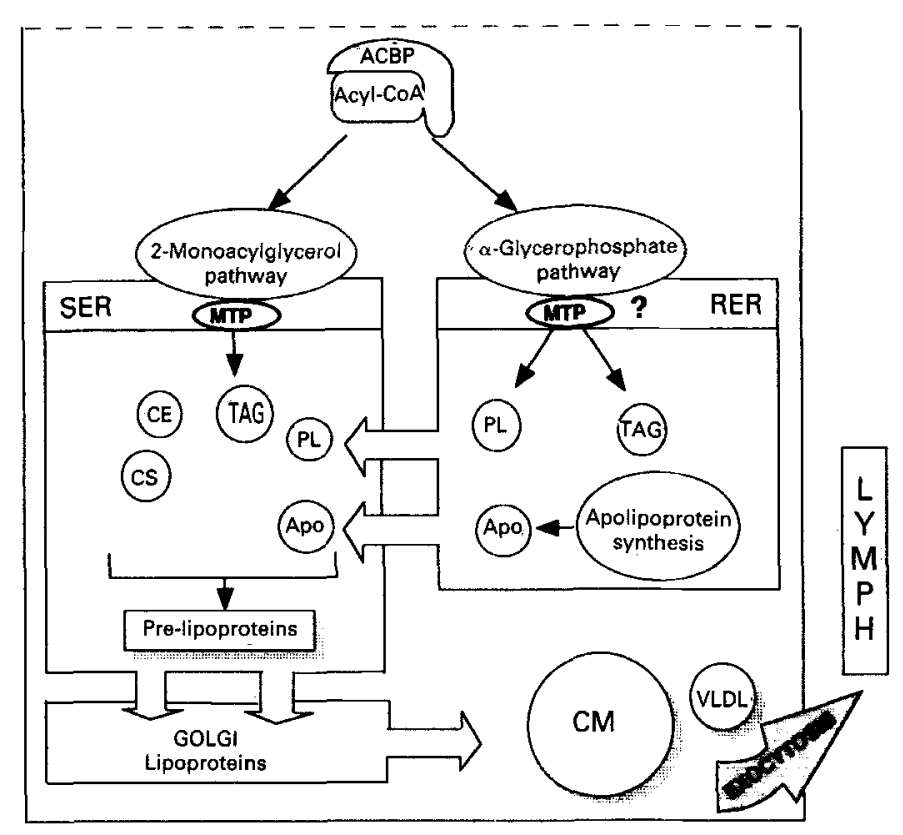

Fig. 2. Lipoprotein synthesis and packaging in the small intestine. SER, smooth endoplasmic reticulum; RER, rough endoplasmic reticulum; MTP, microsomal triacylglycerol transfer protein; TAG, triacylglycerols; CS, cholesterol; CE, cholesteryl esters; PL, phospholipids; apo, apoprotein; CM, chylomicrons.

\section{LIPOPROTEIN FORMATION}

Although the acyl-CoA esters may also be oxidized and/or transformed (saturated, desaturated, elongated or shortened), they are mainly used in the small intestine for further esterification. The esterified products are associated with apolipoproteins to form lipoproteins.

\section{The esterification step}

Two distinct biochemical pathways are involved in TAG synthesis in the enterocyte (Fig. 2). The former, the 2-MAG pathway, uses 2-MAG as an acyl acceptor and the latter, the phosphatidic acid pathway, utilizes $\alpha$-glycerophosphate as acceptor (for review, see Tso, 1994). During the postprandial period, the 2-MAG pathway is by far the more important, while the $\alpha$-glycerophosphate pathway becomes dominant during the interprandial period and fasting. The enzymes involved in the 2-MAG pathway are located in the cytoplasmic face of the smooth endoplasmic reticulum (Friedman \& Cardell, 1977; Bell et al. 1981), whereas those involved in the phosphatidic acid pathway are associated with the rough endoplasmic reticulum (Higgins \& Barnett, 1971). After esterification, the newly synthesized TAG enter the cisternae of the endoplasmic reticulum via the microsomal TAG transfer protein (MTP; Lin et al. 1994; Table 1 and Fig. 2). This protein, which can also promote cholesteryl ester and phosphatidylcholine transfer, is an heterodimer with two subunits of 58 and $88 \mathrm{kDa}$. The lack of MTP expression in 
Table 3. Main characteristics of intestinal lipoproteins

\begin{tabular}{lccc}
\hline \hline & Chylomicrons & VLDL & HDL \\
\hline Size $(\mu \mathrm{m})$ & $0 \cdot 07-0.6$ & $0 \cdot 028-0.07$ & $0 \cdot 005-0 \cdot 015$ \\
Major apolipoproteins & B48, AI, AIV & B48, AI, AIV & AI \\
$\begin{array}{c}\text { Major lipids } \\
(\% \text { of total lipids) }\end{array}$ & TAG 95 & TAG 90 & CS 32 \\
$\begin{array}{c}\text { Protein content } \\
(\% \text { of total lipoprotein) }\end{array}$ & 2 & 10 & 50 \\
\hline \hline
\end{tabular}

TAG, triacylglycerols; CS, cholesterol.

abetalipoproteinaemic patients whose apo $\mathbf{B}$ synthesis was normal, suggests that MTP plays an essential role in lipoprotein assembly and secretion (Wetterau et al. 1992).

\section{Lipoprotein assembly and secretion}

Since several recent reviews have been devoted to lipoprotein metabolism (Glickman \& Sabesin, 1994; Shepherd, 1994; Black, 1995), only the main characteristics of intestinal lipoprotein assembly and exocytosis are reported here.

Morphological aspects of the assembly, intracellular transport and exocytosis of lipoproteins in the small intestine have been investigated by electron microscopy and electron microscope radioautography (Cardell et al. 1967; Carlier, 1976; Sabesin \& Frase, 1977; Bernard et al. 1979). The ultrastructural features of murine enterocytes after the ingestion of a high-fat diet are illustrated in Plate 1. Within minutes of the delivery of the fat bolus, large lipid droplets appear in the endoplasmic reticulum saccules located in the apical cytoplasm of enterocytes (Plate $1(\mathrm{~A})$ ). Then the extension and the swelling of Golgi vesicles containing many structured lipoproteins in the supranuclear area is observed (Plate 1 (B)); these secretory vesicles fuse with the lateral plasma membrane of the enterocyte and deliver the newly synthesized lipoproteins by exocytosis along the lateral plasma membrane (Plate 1 (C)). Finally, lipoproteins may be observed successively in the intercellular spaces, lymphatic capillaries of the villus and in mesenteric lymph (Plate 1 (D-E); Bernard et al. 1979; Caselli et al. 1979). As shown in Plate 1 (A), no obvious synchronous relationship exists between adjacent enterocytes since one cell may be actively engaged in lipid absorption while others show no indications of such activity (Cardell et al. 1967). Several immunological and biochemical observations also demonstrate that lipoproteins are progressively constructed through the endo-membrane system of the cell (Kessler et al. 1975; Christensen et al. 1987; Fig. 2). However, the molecular mechanism by which the apolipoproteins and the lipid particles are associated is still unknown.

The small intestine produces three different types of lipoproteins which transport and deliver lipids to peripheral tissue and liver (Table 3 ). In contrast to apo AI and AIV, apo $\mathrm{B}$ exhibits two isoforms: apo B-100 and apo B-48 which are produced by the liver and small intestine respectively. A single gene produces these two forms by a post-transcriptional modification of the mRNA, called mRNA editing (Powell et al. 1987). Apo B-48 consists of the amino-terminal $48 \%$ of apo B-100.

Chylomicrons (CM) are large spherical particles produced exclusively by the small 


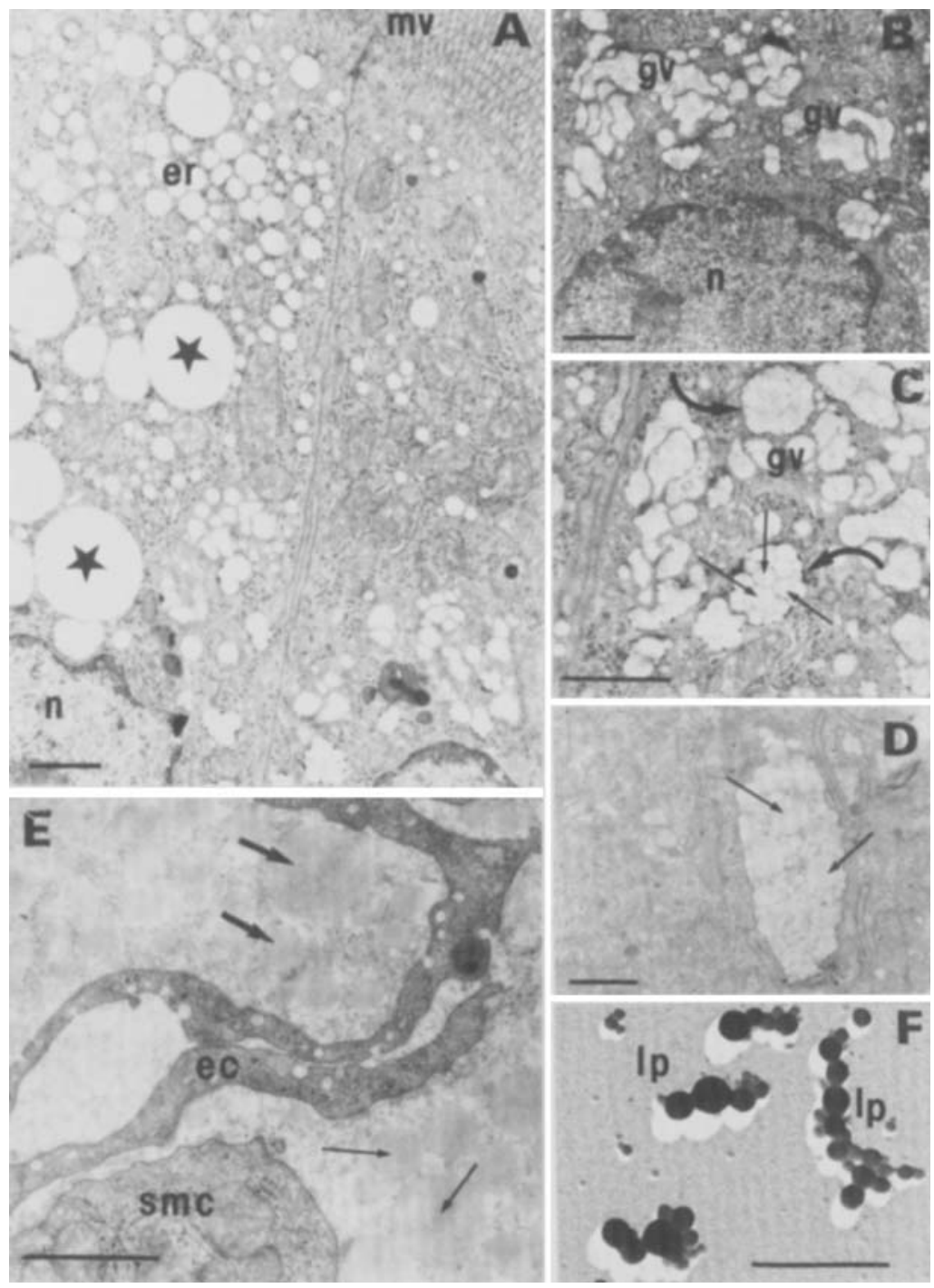

Plate 1. Lipoprotein formation and secretion. (A) Micrograph of jejunum of rat $2 \mathrm{~h}$ after ingestion of a high-fat diet containing $200 \mathrm{~g}$ canbra oil $/ \mathrm{kg}(\times 10000)$ showing the cytoplasm between microvilli (mv) and nucleus (n) and many endoplasmic reticulum vesicles (er) containing large lipid droplets ( $\star$ ). (B) Micrograph of supranuclear area of rat jejunum $0.5 \mathrm{~h}$ after ingestion of a high-fat diet containing $200 \mathrm{~g}$ peanut oil $/ \mathrm{kg}$. The extension of Golgi vesicles (gv) can be observed $(\times 10000)$. (C) Micrograph of secretory rat jejunum $0.5 \mathrm{~h}$ after ingestion of a high-fat diet containing $200 \mathrm{~g}$ canbra oil $/ \mathrm{kg}$ showing Golgi vesicles $(\rightarrow$ ) containing structured lipoproteins $(\rightarrow)$ before their exocytosis $(\times 20000)$. (D) Micrograph of an intercellular space between rat jejunum enterocytes $2 \mathrm{~h}$ after ingestion of a high-fat diet containing $200 \mathrm{~g}$ canbra oil/kg. Many lipoproteins of different size $(\rightarrow)$ were formed $(\times 10000)$. (E) Micrograph of rat mesenteric lymph capillary, $2 \mathrm{~h}$ after ingestion of canbra oil. The capillary is largely dilated by the presence of lipoproteins $(\rightarrow, \rightarrow)$. ec, endothelial cell; smc, smooth muscle cell $(\times 20000)$. (F) Micrograph of lymph lipoprotein particles (lp) collected by fistulation of the main mesenteric lymph vessel in rat during the third hour after ingestion of a high-fat diet containing $200 \mathrm{~g}$ peanut oil $/ \mathrm{kg}(\times 20000)$. All micrographs were obtained using a transmission electron microscope (Hitachi HU 11E) 
intestine (Plate 1 (F)). They are TAG-rich lipoproteins mainly comprising dietary lipids and are the major form produced by the small intestine. A smaller TAG-rich molecule, the intestinal VLDL, is synthesized during both the inter-prandial periods and fasting. It transports absorbed biliary lipids and lipids from sloughed enterocytes. The molecular composition of intestinal VLDL is distinct from that of liver VLDL (for details, see Black, 1995). Finally, the small intestine also synthesizes nascent HDL which are involved in reverse cholesterol transport.

\section{REGULATION OF GENES INVOLVED IN FAT METABOLISM}

Among all the proteins involved in intestinal LCFA metabolism, the regulation of gene expression of LBP and apolipoproteins has been studied particularly. Knowledge of the molecular events controlling the expression of these proteins is crucial to understanding the different steps of intestinal fat absorption and in the future to correcting some disorders.

\section{Regulation of lipid-binding proteins ( $L B P$ )}

The fibrates are hypolipidaemic drugs triggering peroxisome proliferation in most rodents. They are strong inducers of several genes involved in lipid metabolism. Recently, we have demonstrated that the L-FABP $\mathrm{c}$ gene is transcriptionally induced by bezafibrate both in liver and small intestine (Besnard et al. 1993; Mallordy et al. 1995; Fig. 3). Interestingly, ACBP and L-FABP are enhanced by peroxisome proliferators in the liver (Van Den Heuvel et al. 1993; Sterchele et al. 1994) and FAT mRNA are also highly increased in the duodeno-jejunum from rats or mice chronically treated with bezafibrate (P. Besnard, H. Poirier and P. Degrace, unpublished results). It is well established that peroxisome proliferators exert their genomic effects through a class of transnuclear regulators termed peroxisome proliferator-activated receptors (PPAR; Issemann \& Green, 1990). The PPAR are members of the steroid and thyroid superfamily of nuclear receptors (see Keller \& Wahli, 1993; Motojima, 1993). Several distinct PPAR have been described which show a distinct spatial and temporal pattern of expression. The binding of a PPAR to a peroxisome proliferator-responsive element (PPRE) found in the promoter of a target gene triggers the transcription process. PPRE consensus sequences are found in the promoter of the L-FABP $P_{c}$ (Issemann et al. 1992; Simon et al. 1993), ACBP (Mandrup et al. 1993). The repeated fourteen-nucleotide sequences found in the promoter of I-FABP ${ }_{c}$ (Sweetser et al. 1988) exhibit high homology with the PPRE consensus sequence and a direct repeat-like element is found in the promoter of human CD 36, a homologue of FAT (Armesilla \& Vega, 1994). Interestingly, PPAR are activated also by physiological concentrations of LCFA (Göttlincher et al. 1992; Schmidt et al. 1992; Dreyer et al. 1993). In adipocytes, LCFA lead to transcriptional induction of various LBP including ALBP (Amri et al. 1991) and Mal 1 (Ibrahimi et al. 1994), the two isoforms of $\mathrm{FABP}_{c}$ expressed in the adipose tissue and FAT (Amri et al. 1995) through the activation of a new member of the PPAR family, termed fatty acid-activated receptor (FAAR; Amri et al. 1995). Since PPAR $\alpha$ and FAAR are found in the small intestine (Beck et al. 1992; Amri et al. 1995) and L-FABP is transcriptionally up-regulated by dietary fats (Mallordy et al. 1995; Fig. 3), it is tempting to speculate that LBP involved in intestinal FA absorption are regulated via a transprotein activated by LCFA. The fact that jejunal FAT mRNA level (P. Besnard, 


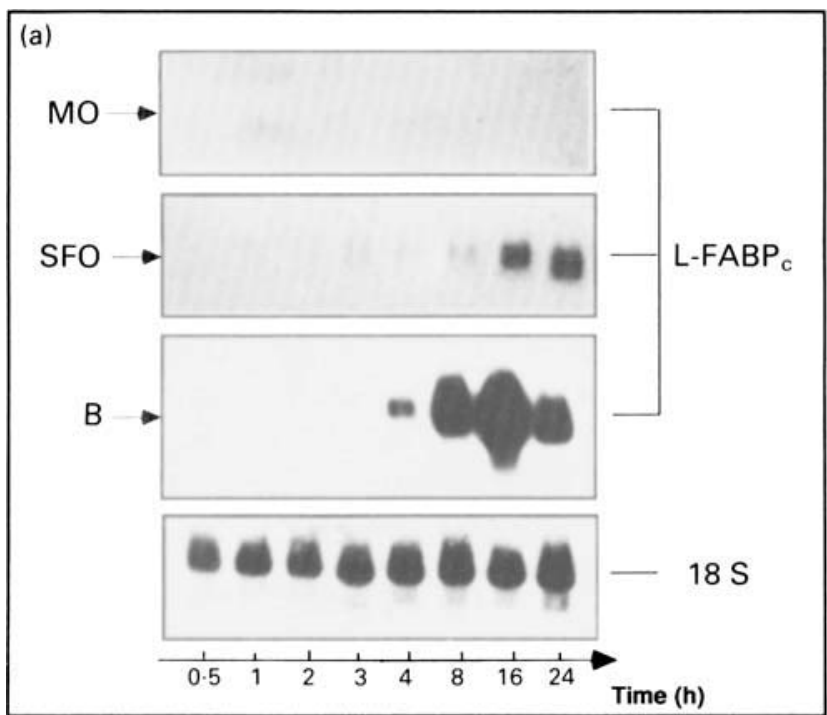

(b)

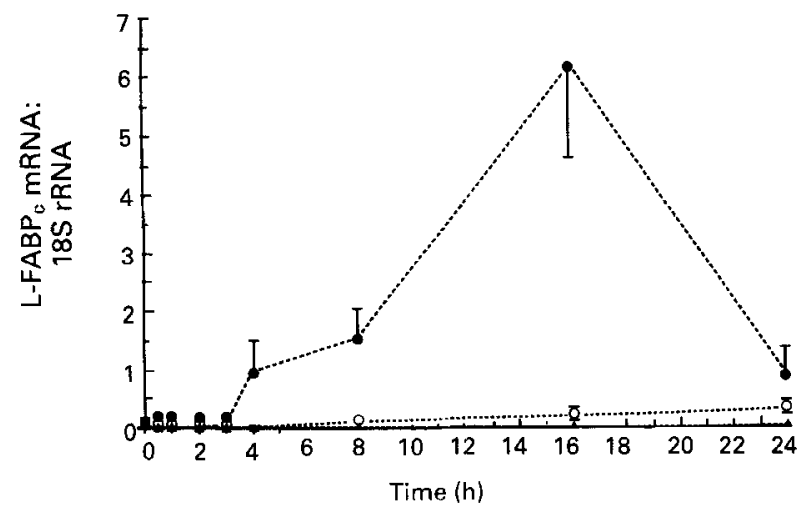

Fig. 3. Time-course of liver fatty acid-binding protein (L-FABP) mRNA production in mouse terminal ileum after direct infusion of mineral oil (MO), sunflower oil (SFO) or bezafibrate (B). (a), Northern-blot analysis of $20 \mu \mathrm{g}$ total RNA; (b), means of three independent experiments. Mice were infused with $0.2 \mathrm{ml} \mathrm{MO}(\Delta), 0.2 \mathrm{ml}$ $\mathrm{SO}(\mathrm{O}), 400 \mathrm{mg} \mathrm{B} / \mathrm{kg}$ body mass plus SO (O), or were untreated (a). The amounts of total mRNA sampled were checked using an $18 \mathrm{~S}$ mRNA probe. Values are means with their standard errors represented by vertical bars. (From Mallordy et al. 1995. Reproduced with the permission of the European Journal of Biochemistry.)

H. Poirier and P. Degrace, unpublished results) and MTP expression (Lin et al. 1994) are highly induced in rats fed on various high-fat diets, provides further support for this hypothesis.

\section{Regulation of apolipoproteins}

The molecular mechanisms involved in the regulation of the main apolipoproteins expressed in the small intestine are still unknown. However, it has been established that apo B, apo AI and apo AIV genes are up- or down-regulated by members of the orphan 
nuclear hormone transcription factors family such as ARP1, HNF4, Ear3/COUP-TF and $\mathrm{RXR} \alpha$ (Laudet et al. 1992) via unknown factors. Some of these transproteins, such as HNF4 and Ear3/COUP-TF or RXR $\alpha$ and ARP1, exert functional antagonist effects through direct competition for binding to the same DNA response element of the apo AIV (Ochoa et al. 1993) and apo A1 (Ge et al. 1994) genes respectively. These results suggest that these receptors are closely related to lipid metabolism.

The effect of drugs such as fibrates and high-fat diets on intestinal lipoproteins and LBP expression seem to involve different regulatory mechanisms, since fibrates repress the apo AI gene through a PPAR-independent mechanism (Vu-Dac et al. 1994) and dietary lipids induce the apo genes via a post-transcriptional mechanism. Indeed, the results of studies with human subjects indicate that the significant increase in apo B-48 within TAG-rich lipoproteins in postprandial plasma is not due to alterations in apo $\mathrm{B}$ gene transcription rate or editing, the major regulatory event being the modulation of the protein intracellular degradation (Lopez-Miranda et al. 1994). Moreover, immunofluorescence studies have demonstrated the presence of apo-B and apo-A pools in the enterocytes before feeding fat (Glickman et al. 1976). In rat pups, the administration of Intralipid promptly increases the apo AIV mRNA level. Since the transcription rate of the apo AIV gene tested by nuclear run-on assay is unchanged, the dietary-fatdependent level of intestinal apo AIV mRNA appears to be regulated mainly by post-transcriptional events inducing the stabilization of the apo AIV mRNA (Sato et al. 1992). Similar results are reported in the piglet (Black et al. 1990). In mice, unaltered apo AI mRNA levels found in liver after high-fat diet administration suggest that the increases in plasma apo AI and HDL levels were not the result of a transcriptional mechanism (Srivastava, 1994). In piglets, dietary lipids induce a 2 -fold increase in apo AI synthesis in jejunum, but the regulation takes place at a translational level (Trieu et al. 1992).

In conclusion, several key proteins involved in intestinal lipid metabolism seem to be regulated by members of the steroid-receptor superfamily which are activated by unknown ligands. These receptors might bind intracellular molecules generated during lipid metabolism, reflecting the instantaneous metabolic state of the cell and bringing the appropriate changes in the gene expression. Identification of such ligands may provide important insights into the molecular mechanisms linking physiological signals to lipid metabolism. Recent findings have shown that LCFA or their derivatives may play this role since they may coordinately regulate several genes involved in lipid metabolism in adipose tissue. The data reported for the LBP strongly suggest that similar regulatory mechanisms also exist in the small intestine.

\section{REFERENCES}

Abumrad, N. A., El-Magrabi, M. R., Amri, E. Z., Lopez, E. \& Grimaldi, P. A. (1993). Cloning of a rat adipocyte membrane protein implicated in binding or transport of long-chain fatty acid that is induced during preadipocyte differentiation. Journal of Biological Chemistry 268, 17665-17668.

Ailhaud, G. P., Abumrad, N. A., Amri, E. Z. \& Grimaldi, P. A. (1994). A new look at fatty acids as signal-transducing molecules. In Fatty Acids and Lipids Biological Aspects, vol. 75, pp. 35-45 [C. Galli, A. P. Simopoulos and E. Tremoli, editors]. Basel: Karger Press.

Alpers, D. H., Strauss, A. W., Ockner, R. K., Bass, N. M. \& Gordon, J. I. (1984). Cloning of a cDNA encoding rat intestinal fatty acid-binding protein. Proceedings of the National Academy of Sciences, USA 81, 313-317.

Amri, E. Z., Bertrand, B., Ailhaud, G. \& Grimaldi, P. (1991). Regulation of adipose cell differentiation. I- Fatty acids are inducers of the aP2 gene expression. Journal of Lipid Research 32, 1449-1456. 
Amri, E. Z., Bonino, F., Ailhaud, G., Abumrad, N. A. \& Grimaldi, P. A. (1995). Cloning a protein that mediates transcriptional effects of fatty acids in preadipocytes. Homology to peroxisome proliferatoractivated receptors. Journal of Biological Chemistry 270, 2367-2371.

Armesilla, A. L. \& Vega, M. A. (1994). Structural organization of the gene for the human CD 36 glycoprotein. Journal of Biological Chemistry 269, 18985-18991.

Bass, N. M., Manning, J. A., Ockner, R. K., Gordon, J. I., Seetharam, S. \& Alpers, D. H. (1985). Regulation of biosynthesis of two fatty acid-binding proteins in rat liver and intestine: influence of sex difference and of clofibrate. Journal of Biological Chemistry 260, 1432-1436.

Beck, F., Plummer, S., Senior, P. V., Byrne, S., Green, S. \& Brammar, W. J. (1992). The ontogeny of peroxisome-proliferator-activated receptor gene expression in the mouse and rat. Proceedings of Royal Society of London 247, 83-87.

Bell, R. M., Ballas, L. M. \& Coleman, R. A. (1981). Lipid topogenesis. Journal of Lipid Research 22, 391-403.

Berk, P. D., Wada, H., Horio, Y., Potter, B. J., Sorrentino, D., Zhou, S. L., Isola, L. M., Stump, D., Kiang, C. L. \& Thung, S. (1990). Plasma membrane fatty acid-binding protein and mitochondrial glutamicoxaloacetic transaminase of rat liver are related. Proceedings of the National Academy of Sciences, USA 87, 3484-3488.

Bernard, A., Caselli, C., Carlier, H. \& Bézard, J. (1979). Electron microscopic investigation of the intestinal epithelial cells and the lipoprotein particles of lymph in rats after ingestion of peanut, canbra and rapeseed oil in the diet. Journal de Physiologie, Paris 75, 559-570.

Besnard, P., Mallordy, A. \& Carlier, H. (1993). Transcriptional induction of the fatty acid binding protein gene in mouse liver by bezafibrate. FEBS Letters 327, 219-223.

Black, D. D. (1995). Intestinal lipoprotein metabolism. Journal of Pediatric Gastroenterology and Nutrition 20, 125-147.

Black, D. D., Rohwer-Nutter, P. L. \& Davidson, N. O. (1990). Intestinal apo A IV gene expression in the piglet. Journal of Lipid Research 31, 497-505.

Campbell, F. M., Gordon, M. J. \& Dutta-Roy, A. K. (1994). Plasma membrane fatty acid binding protein (FABPpm) of the sheep placenta. Biochimica et Biophysica Acta 1214, 187-192.

Cardell, R. R. Jr, Badenhausen, S. \& Porter, K. R. (1967). Intestinal triglyceride absorption in the rat. An electron microscope study. Journal of Cellular Biology 34, 123-155.

Carlier, H. (1976). Detection of radioactive fatty acids during their intestinal absorption by the rat. Journal de Microscopie et de Biologie Cellulaire 27, 239-242.

Caselli, C., Carlier, H. \& Bézard, J. (1979). Size of lipoprotein particles in the intestinal lymph of rats fed on corn oil, peanut oil, rapeseed oil or canbra oil. Nutrition and Metabolism 23, 73-87.

Chan, L., Wei, C. F., Li, W. H., Yang, C. Y., Ratner, P., Pownall, H., Gotto, A. M. Jr \& Smith, L. C. (1985). Human liver fatty acid-binding protein cDNA and amino acid sequence. Functional and evolutionary implications. Journal of Biological Chemistry 260, 2629-2632.

Christensen, N. J., Rubin, C. E., Cheung, M. C. \& Albers, J. J. (1983). Ultrastructural immunolocalization of apoprotein B within human jejunal absorptive cells. Journal of Lipid Research 24, 1229-1242.

Chytil, F. \& Ong, D. E. (1987). Intracellular vitamin A-binding proteins. Annual Review of Nutrition 7, 321-335.

Cistola, D. P., Sacchettini, J. C., Banaszak, L. J., Walsh, M. T. \& Gordon, J. I. (1989). Fatty acid interactions with intestinal and liver fatty acid-binding proteins expressed in Escherichia coli. A comparative 13C NMR study. Journal of Biological Chemistry 264, 2700-2710.

Davidson, N. O. (1994). Cellular and molecular mechanisms of small intestinal lipid transport. In Physiology of the Gastrointestinal Tract, 3rd ed., pp. 1909-1934 [L. R. Johnson, editor]. New York: Raven Press.

Dreyer, C., Keller, H., Mahfoudi, A., Laudet, V., Krey, G. \& Wahli, W. (1993). Positive regulation of the peroxisome beta oxidation pathway by fatty acids through activation of peroxisome proliferator-activated receptors (PPAR). Biology of the Cell 77, 67-76.

Friedman, H. I. \& Cardell, R. R. Jr (1977). Alterations in the endoplasmic reticulum and golgi complex of intestinal epithelial cells during fat absorption and after termination of this process: a morphological and morphometric study. Anatomical Records 188, 77-102.

Ge, R., Rhee, M., Malik, S. \& Karathanasis, S. K. (1994). Transcriptional repression of apolipoprotein AI gene expression by orphan receptor ARP-1. Journal of Biological Chemistry 269, 13185-13192.

Glatz, J. F. C., Borchers, T., Spener, F. \& Van Der Vusse, G. J. (1995). Fatty acids in cell signalling: Modulation by lipid binding proteins. Prostaglandins, Leukotrienes and Essential Fatty Acids 52, 121-127.

Glatz, J. F. C., Vork, M. M., Cistola, P. D. \& Van Der Vusse, G. J. (1993). Cytoplasmic fatty acid binding protein: significance for intracellular transport of fatty acids and putative role on signal transduction pathways. Prostaglandins, Leukotrienes and Essential Fatty Acids 48, 33-41. 
Glickman, R. M., Khonara, J. \& Kilgore, A. (1976). Localization of apoprotein B in intestinal epithelial cells. Science 193, 1254-1255.

Glickman, R. M. \& Sabesin, S. M. (1994). Lipoprotein metabolism. In The Liver: Biology and Pathology, 3rd ed., pp. 391-414 [I. M. Arias, J. L. Boyer, N. Fausto, W. B. Jakobi, D. A. Schachter and D. A. Shafritz, editors]. New York: Raven Press.

Gordon, J. I., Alpers, D. H., Ockner, R. K. \& Strauss, A. W. (1983). The nucleotide sequence of rat liver fatty acid-binding protein mRNA. Journal of Biological Chemistry 258, 3356-3363.

Göttlichter, M., Widmark, E., Li, Q. \& Gustufsson, J. A. (1992). Fatty acids activate a chimera of clofibric acid-activated receptor and glucocorticoid receptor. Proceedings of the National Academy of Sciences, USA 89, 4653-4657.

Harmon, C. M., Luce, P., Beth, A. H. \& Abumrad, N. A. (1991). Labeling of adipocyte membranes by sulfo- $\mathrm{N}$-succinimidyl derivatives of long chain fatty acids inhibition of fatty acid transport. Journal of Membrane Biology 121, 261-268.

Higgins, J. G. \& Barnett, R. J. (1971). Fine structural localization of acyl-transferase. Journal of Cellular Biology 50, 102-120.

Ibrahimi, A., Teboul, L., Gaillard, D., Amri, E. Z., Ailhaud, G. \& Grimaldi, P. (1994). Evidence for a common mechanism of action for fatty acids and thiazolinedione antidiabetic agents on gene expression in preadipose cells. Molecular Pharmacology 46, 1070-1076.

Issemann, I. \& Green, S. (1990). Activation of a member of the steroid hormone receptor superfamily by peroxisome proliferators. Nature 347, 645-650.

Issemann, I., Prince, R., Tugwood, J. \& Green, S. (1992). A role for fatty acids and liver fatty acid binding protein in peroxisome proliferation. Biochemical Society Transactions $\mathbf{2 0 ,}$ 824-827.

Kamp, F., Westterhoff, H. V. \& Hamilton, J. A. (1993). Movement of fatty acids, fatty acid analogues and bile acids across phospholipid bilayers. Biochemistry 32, 11074-11086.

Keller, H. \& Wahli, W. (1993). Peroxisome proliferator-activated receptors. A link between endocrinology and nutrition? Trends in Endocrinology and Metabolism 4, 291-296.

Kessler, J., Narcessian, P. \& Mauldin, D. P. (1975). Biosynthesis of lipoproteins by intestinal epithelium. Site of synthesis and sequence of association of lipid, sugar and protein moieties. Gastroenterology 68, 1058 Abstr.

Knudsen, J. (1990). Acyl-CoA-binding protein (ACBP) and its relation to fatty acid-binding protein (FABP). Molecular and Cellular Biochemistry 98, 217-223.

Knudsen, J., Hojrup, P., Hansen, H. O., Hansen, H. F. \& Roepstorff, P. (1989). AcylCoA binding protein in the rat. Purification, binding characteristics, tissue concentrations and amino acid sequence. Biochemical Journal 262, 513-519.

Knudsen, J., Mandrup, S., Rasmussen, J. T., Andreasen, P. H., Poulsen, F. \& Kristiansen, K. (1993). The function of acyl-CoA-binding protein (ACBP)/diazepam binding inhibitor. Molecular and Cellular Biochemistry 123, 129-138.

Kragelund, B. B., Andersen, K. V., Madsen, J. C., Knudsen, J. \& Poulsen, F. M. (1993). Three-dimensional structure of the complex between acyl-coenzyme A binding protein and palmitoyl-coenzyme A. Journal of Molecular Biology 230, 1260-1277.

Krisans, S. K., Mortensen, R. M. \& Lazarow, P. B. (1980). Acyl-CoA synthetase in rat liver peroxisomes. Computer-assisted analysis of cell fractionation experiments. Journal of Biological Chemistry 255, 9599-9607.

Laudet, V., Hänni, C., Coll, J., Catzeflis, F. \& Stéhelin, D. (1992). Evolution of the nuclear receptor gene superfamily. EMBO Journal 11, 1003-1013.

Lin, M. C. M., Arbeeny, C., Berquist, K., Kienzle, B., Gordon, D. A. \& Wetterau, J. R. (1994). Cloning and regulation of hamster microsomal triglyceride transfer protein. Journal of Biological Chemistry 269, 29138-29145.

Lopez-Miranda, J., Kam, N., Osada, J., Rodriguez, C., Fernandez, P., Contois, J., Schaefer, E. J. \& Ordovas, J. M. (1994). Effect of fat feeding on human intestinal apolipoprotein B mRNA levels and editing. Biochimica et Biophysica Acta 1214, 143-147.

Lowe, J. B., Sacchettini, J. C., Laposata, M., McQuillan, J. J. \& Gordon, J. I. (1987). Expression of rat intestinal fatty acid-binding protein in Escherichia coli. Purification and comparison of ligand binding characteristics with that of Escherichia coli-derived rat liver fatty acid binding protein. Journal of Biological Chemistry 262, 5931-5937.

Mallordy, A., Poirier, H., Besnard, P., Niot, I. \& Carlier, H. (1995). Evidence for transcriptional induction of the liver fatty acid binding protein gene by bezafibrate in the small intestine. European Journal of Biochemistry 227, 801-807. 
Mandrup, S., Andreasen, P. H., Knudsen, J. \& Kristiansen, K. (1993). Genome organization and expression of the rat ACBP gene family. Molecular and Cellular Biochemistry 123, 55-61.

Mandrup, S., Jepsen, R., Skott, H., Rosendal, J., Hojrup, P., Kristiansen, K. \& Knudsen, J. (1992). Effect of heterologous expression of acyl CoA binding protein (ACBP)/diazepam-binding inhibitor (DBI) on the acyl-CoA level and composition in yeast. Biochemical Journal 290, 369-374.

Mogensen, I. B., Schulenberg, H., Hansen, H. O., Spener, F. \& Knudsen, J. (1987). A novel acyl-CoAbinding protein from bovine liver. Effect of fatty acid synthesis. Biochemical Journal 241, 189-192.

Motojima, K. (1993). Peroxisome proliferator-activated receptor (PPAR): structure, mechanisms of activation and diverse functions. Cell Structure and Function 18, 267-277.

Noland, J. B., Arebalo, R. E., Hansbury, E. \& Scallen, T. J. (1980). Purification and properties of sterol carrier protein 2. Journal of Biological Chemistry 255, 8042-8045.

Ochoa, A., Bovard-Houppermans, S. \& Zakin, M. M. (1993). Human apolipoprotein AIV gene expression is modulated by members of the nuclear hormone receptor superfamily. Biochimica et Biophysica Acta 1210, $41-47$.

Ordway, R. W., Singer, J. J. \& Walsh, J. V. Jr (1991). Direct regulation of ion channels by fatty acids. Trends in Neurosciences 14, 96-100.

Potter, J. B., Stump, D., Schwieterman, W., Sorrentino, D., Jacobs, L. N., Kiang, C. L., Rand, J. H. \& Berk, P. D. (1987). Isolation and partial characterization of plasma membrane fatty acid-binding proteins from myocardium and adipose tissue and their relationship to analogous proteins in the liver and gut. Biochemical and Biophysical Research Communications 148, 1370-1376.

Powell, L. M., Wallis, S. C., Pease, R. J., Edwards, Y. H., Knott, T. J. \& Scott, J. (1987). A novel form of tissue-specific RNA processing produces apolipoprotein-B48 in intestine. Cell 50, 831-840.

Rasmussen, J. T., Faergeman, N. J., Kristiansen, K. \& Knudsen, J. (1994). Acyl-CoA-binding protein (ACBP) can mediate intermembrane acyl-CoA transport and donate acyl-CoA for $\beta$-oxidation and glycerolipid synthesis. Biochemical Journal 299, 165-170.

Richieri, G. V., Ogata, R. T. \& Kleinfeld, A. M. (1994). Equilibrium constants for the binding of fatty acids with fatty acid-binding proteins from adipocyte, intestine, heart and liver measured with fluorescent probe ADIFAB. Journal of Biological Chemistry 269, 23918-23930.

Rosendal, J., Etbjeerg, P. \& Knudsen, J. (1993). Characterization of ligand binding to acyl-CoA-binding protein (ACBP)/diazepam binding inhibitor (DBI). Biochemical Journal 290, 321-326.

Sabesin, M. S. \& Frase, S. (1977). Electron microscopic studies of assembly, intracellular transport and secretion of chylomicrons by rat intestine. Journal of Lipid Research 18, 496-511.

Sacchettini, J. C. \& Gordon, J. I. (1993). Mini review: rat intestinal fatty acid-binding protein. A model system for analyzing the forces that can bind fatty acids to proteins. Journal of Biological Chemistry 268, 18399-18402.

Sacchettini, J. C., Gordon, J. I., \& Banaszak, L. J, (1988). The structure of crystalline Escherichia coli-derived rat intestinal fatty acid-binding protein at 2.5 Angstroms resolution. Journal of Biological Chemistry 263, 5815-5819.

Sato, M., Imaizumi, K., Mori, H. \& Sugano, M. (1992). Regulation of intestinal apo A-IV mRNA abundance in rat pups during fasting and refeeding. Biochimica et Biophysica Acta 1165, 93-101.

Schaffer, J. E. \& Lodish, H. F. (1994). Expression cloning and characterization of a novel adipocyte long chain fatty acid transport protein. Cell 79, 427-436.

Schmidt, A., Endo, N., Rutledge, S. J., Vogel, R., Shinar, D. \& Rodan, G. A. (1992). Identification of a new member of the steroid hormone receptor superfamily that is activated by a peroxisome proliferator and fatty acid. Molecular Endocrinology 6, 1634-1641.

Schoonjans, K., Staels, B., Grimalgi, P. \& Auwerx, J. (1993). Acyl-CoA synthetase mRNA expression is controlled by fibric-acid derivatives, feeding and liver proliferation. European Journal of Biochemistry 216, 615-622.

Shepherd, J. (1994). Lipoprotein metabolism. An overview. Drugs 47, 1-10.

Shiau, Y. F. (1981). Mechanism of fat absorption. American Journal of Physiology 240, G1-G9.

Shiau, Y. F., Fernandez, P., Jackson, M. J. \& McMonagle, S. (1985). Mechanisms maintaining a low pH microclimate in the intestine. American Journal of Physiology 248, G608-G617.

Shields, H. M., Bates, M. L., Bass, N. M., Alpers, D. H. \& Ockner, R. K. (1986). Light microscopic immunohistochemical localization of hepatic and intestinal types of fatty acid-binding proteins in rat small intestine. Journal of Lipid Research 27, 549-557.

Simon, T. C., Roth, K. A. \& Gordon, J. I. (1993). Use of transgenic mice to map cis-acting elements in the liver fatty acid binding protein gene (Fabpl) that regulate its cell lineage-specific, differentiation-dependent and spatial patterns of expression in the gut epithelium and in the liver acinus. Journal of Biological Chemistry 268, 18345-18358. 
Sorof, S. (1994). Modulation of mitogenesis by liver fatty acid binding proteins. Cancers and Metastasis Review 13, 317-336.

Srivastava, R. A. K. (1994). Saturated fatty acid but not cholesterol regulates apolipoprotein A-I gene expression by post-transcriptional mechanism. Biochemistry and Molecular Biology International 34, 393-402.

Sterchele, P. F., Van Den Heuvel, J. P., Davis, J. W. II, Shrago, E., Knudsen, J. \& Peterson, R. E. (1994). Induction of hepatic acyl CoA-binding protein and liver fatty acid binding protein by perfluorodecanoic acid in the rat. Lack of correlation with hepatic long chain acyl CoA levels. Biochemical Pharmacology 48, 955-966.

Stremmel, W. (1987). Translocation of fatty acids across the basolateral rat liver plasma membrane is driven by an active potential-sensitive sodium-dependent transport system. Journal of Biological Chemistry 262, 6284-6289.

Stremmel, W. (1988). Uptake of fatty acids by jejunal mucosa cells is mediated by a fatty acid-binding protein membrane protein. Journal of Clinical Investigation 82, 2001-2010.

Stremmel, W., Lotz, G., Strohmeyer, G. \& Berk, P. D. (1985b). Identification, isolation and partial characterization of a fatty acid-binding protein from rat jejunum microvillus membranes. Journal of Clinical Investigation 75, 1068-1076.

Stremmel, W., Strohmeyer, G., Borchard, F., Kochwa, S. \& Berk, P. D. (1985a). Isolation and partial characterization of a fatty acid-binding protein in rat liver plasma membranes. Proceedings of the National Academy of Sciences, USA 82, 4-8.

Stump, D. D., Zhou, S. L. \& Berk, P. D. (1993). Comparison of plasma membrane fatty acid-binding protein and mitochondrial isoform of aspartate aminotransferase from rat liver. American Journal of Physiology 265, G894-G902.

Sumida, C. (1995). Fatty acids: ancestral ligands and modern co-regulators of steroid hormone receptor cell signalling pathway. Prostaglandins, Leukotrienes and Essential Fatty Acids 52, 137-144.

Suzuki, H., Kawarabayasi, Y., Kondo, J., Abe, T., Nishikawa, K., Kimura, S., Hashimato, T. \& Yamamoto, T. (1990). Structure and regulation of rat long-chain acyl-CoA synthetase. Journal of Biological Chemistry 265, 8681-8685.

Sweetser, D. A., Birkenmeier, E. H., Hoppe, P. C., McKeel, D. W. \& Gordon, J. I. (1988). Mechanisms underlying a generation of gradients in gene expression within intestine: an analysis using transgenic mice containing fatty acid-binding protein/human growth hormone fusion genes. Genes and Development $\mathbf{2}$, 1318-1332.

Sweetser, D. A., Birkenmeier, E. H., Klisak, I. J., Zollman, S., Sparkes, R. S., Mohandas, T., Lusis, A. J. \& Gordon, J. I. (1987). The human and rodent intestinal fatty acid-binding protein genes: a comparative analysis of their structure, expression and linkage relationships. Journal of Biological Chemistry 262, $16060-16071$.

Tanaka, T., Hosaka, K., Hoshimaru, M. \& Numa, S. (1979). Purification and properties of long-chain acyl-coenzyme A synthetase from the rat liver. European Journal of Biochemistry 98, 165-172.

Tandon, N. N., Lipski, R. H., Burgess, W. H. \& Jamieson, G. A. (1989). Isolation and characterization of platelet glycoprotein IV (CD 36). Journal of Biological Chemistry 264, 7570-7575.

Trieu, V. M., Penn, D., Hay, R. V. \& Black, C. C. (1992). Sequence and developmental expression of porcine intestinal and hepatic apolipoprotein A-I mRNA. Gastroenterology 102, A-582.

Trigatti, B. L., Mangroo, D. \& Gerber, G. E. (1991). Photoaffinity labeling and fatty acid permeation in 3T3-L1 adipocytes. Joumal of Biological Chemistry 266, 22621-22625.

Tso, P. (1994). Intestinal lipid absorption. In Physiology of the Gastrointestinal Tract, 3rd ed., pp. 1867-1907 [L. R. Johnson, editor]. New York: Raven Press.

Van Den Heuvel, J. P., Sterchele, P. F., Nesbit, D. J. \& Peterson, R. E. (1993). Coordinate induction of acyl-CoA binding protein, fatty acid binding protein and peroxisomal $\beta$-oxidation by peroxisome proliferators. Biochimica et Biophysica Acta 1177, 183-190.

Veerkamp, J. H. (1995). Fatty acid transport and fatty acid-binding proteins. Proceedings of the Nutrition Society 54, 23-37.

Veerkamp, J. H. \& Maatman, R. G. H. J. (1995). Cytoplasmic fatty acid-binding proteins: their structure and genes. Progress in Lipid Research 34, 17-52.

Veerkamp, J. H., Peeters, R. A. \& Maatman, R. G. H. J. (1991). Review: Structural and functional features of different types of cytoplasmic fatty acid-binding proteins. Biochimica et Biophysica Acta 1081, 1-24.

Veerkamp, J. H., Van Kuppevelt, T. H. M. S., Maatman, R. G. H. J. \& Prinsen, C. F. M. (1993). Structural and functional aspects of cytosolic fatty acid-binding proteins. Prostaglandins, Leukotrienes and Essential Fatty Acids 49, 887-906. 
Vu-Dac, N., Schoonjans, K., Laine, B., Fruchart, J. C., Auwerx, J. \& Staels, B. (1994). Negative regulation of the human apolipoprotein A-I promoter by fibrates can be attenuated by the interaction of the peroxisome proliferator-activated receptor with its response element. Journal of Biological Chemistry 269, 31012 31018.

Walz, D. A., Wider, M. D., Snow, J. W., Dass, C. \& Desiderio, D. M. (1988). The complete amino acid sequence of porcine gastrotropin, an ileal protein which stimulates gastric acid and pepsinogen secretion. Journal of Biological Chemistry 263, 14189-14195.

Wettereau, J. R., Aggerbeck, L. P., Bouma, M. E., Eisenberg, C., Munch, A., Hermier, M., Schimtz, J., Gay, G., Rader, D. J. \& Gregg, R. E. (1992). Absence of microsomal triglyceride transfer protein in individuals with abetalipoproteinemia. Science 258, 999-1001. 